\title{
Concrete Modalities of Conducting an University Course
}

Dana Jucan 


\title{
Concrete Modalities of Conducting an University Course
}

\author{
Dana Jucan ${ }^{\mathbf{a}^{*}}$ \\ ${ }^{a}$ Faculty of Psychology and Educational Sciences, Babes-Bolyai University, 7 Sindicatelor Street, 400029, Cluj-Napoca, Romania \\ *Corresponding author: orian_dana@yahoo.com
}

Abstract

Keywords:

Course

Students

Cornell note-taking system

Debate

Reflection
Students differ greatly in what concerns the cognitive structures they possess and regarding the cognitive strategies which they employ during classes. For this reason, in the present article, we propose a certain course of action which would allow the new content to be learned while being understood, due to the fact that the student is able to connect it logically to the cognitive structures already existent, considering that the understanding of knowledge is in its nature a constructive activity. By studying during the classes through the proposed approach and taking notes through the Cornell note-taking system, the students form their own mental systems, their own personal models for the processing of information, and their own personal cognitive style as a result of formulating questions, hypotheses, ideas, and through their proposals for projects, knowledge blocks, and skills. The student debates, structures, and restructures. During classes, the students are thus able to organize and realize cognitive experiences; they are actively engaged in learning mechanisms, they interiorize, reflect, formulate, correlate, all while taking notes. The students develop their ability to organize, within their notes, their educational process in a rational manner, building upon the learning unit or activity. In this way, they can participate in the construction of the learning objectives, of the thematic unit, in other words - in the construction of the content itself. As a result, the autonomy of the students is developed, as well as their initiative, the students being encouraged to use their knowledge, to exercise their imagination and creativity.

Die Studenten unterscheiden sich stark in ihren kognitiven Strukturen und in Bezug auf die kognitiven Strategien, die sie während den Vorlesungen einsetzen. Deshalb schlagen wir in dieser Arbeit eine gewisse Vorgehensweise der Vorlesungen vor, Ansatz bei dem, der neue Inhalt gelernt werden kann, während er verstanden wird, weil der Student den Inhalt der bereits vorhandenen kognitiven Strukturen in einer logischen Weise verbinden kann und das Verständnis von Kenntnissen eine konstruktive Aktivität ist, die von Studenten, anhand kognitiven Strategien, durchgeführt ist. Studieren durch den vorgeschlagenen Ansatz während Vorlesungen und verwenden die Cornell-Methode für Notizen erlauben den Studenten ihre eigenen mentalen Systeme, eigene Modelle der Informationsverarbeitung, eigenen kognitiven Stil zu schaffen, weil der Student Fragen, Hypothesen, Ideen, Schemata formuliert und schlägt Projekte, Blöcke von Wissen, Fähigkeiten vor. Er debattiert, strukturiert und umstrukturiert. Während Vorlesungen organisieren und erleben die Studenten kognitive Erfahrungen, sie sind aktiv engagiert in den Mechanismen des Verstehens; sie verinnerlichen, reflektieren, formulieren, korrelieren und nehmen Notizen. Die Studenten entwickeln ihre Fähigkeit, das Lernen in Notizen zu organisieren und bauen rational um das Thema oder um die Lernaufgabe. Sie beteiligen sich also am Aufbau der Ziele, dem Thema, also dem Inhalt. Die Autonomie und Initiative der Studenten werden entwickelt, sie werden ermutigt, ihr Wissen zu nutzen und ihre Phantasie und Kreativität zu trainieren.

\section{Introduction}

The manner in which students approach learning during courses refers to the superficial or in-depth processing of the scientific content discussed. Even though the teacher can do much towards encouraging the implementation of an in-depth processing of the information (through the content itself and the style of teaching), it is the student that ultimately needs to adopt an individual approach to studying and learning that would result in a deeper engagement with the content and observation of their progress. Stimulating an in-depth approach during classes can also be achieved through various learning activities to which the student is exposed to. The teacher thus stimulates the student to acquire learning skills alongside knowledge of the subject matter, even within the content area. Encouragement to think about what has been thought can coincide with encouragement to think about how to learn; thinking can be stimulated through the student's approach to knowledge that has been newly acquired and scrutinized within their own cognitive scheme.

For the organization of classes where discussions, reflections, etc., are predominant, the individual study strategies and the intellectual activity techniques are carefully proposed by the teacher (Jucan, D., 2009). Therefore, for the teaching-learning activities of the course The Theory and Methodology of Instruction. 
The Theory and Methodology of Assessment, class taught to the $2^{\text {nd }}$ year students of the Faculty of Economics and Business Administration that are also enrolled in the teacher training program, we have proposed a particular course of action which we have presented to the students. Furthermore, we have also presented them with a new note-taking technique, namely the Cornell system, and the students have used the new system or its various methodological alternatives to take their notes during class (Fleming, N. D., \& Mills, C., 1992).

We have chosen this particular note-taking technique bearing in mind that it transforms the operation into an active and conscious process. As such, the active reception of the information and its organization lead to a higher level of understanding, thus raising the accuracy of retention as well (Deese, J., \& Deese, E. K., 1979).

The Cornell system facilitates the intervention of the person who is taking notes upon the content at the same time as the content is heard and recorded. The system also helps in organizing and systematizing the information for its later decoding and reviewing (Entwistle, N. J., \& Ramsden, P., 1983).

\section{The concrete execution of the course}

In what follows, we will describe the manner in which the lesson „The Educational Process - The Main Subsystem of the Educational System. Components of the Educational Process" was executed.

We wrote down the date and the title of the class. We then presented to the students the objectives to be pursued during said class:

O1: Correctly define the concepts: educational process, curriculum, didactic strategies, content of the educational process, form of organization of the educational process, feedback;

O2: Analyze the educational process from a systemic perspective;

O3: Analyze the components of the educational process;

O4: Explain the importance of feedback within the educational process;

O5: Record the information using the Cornell note-taking system.

This being the first course conducted in this manner, we insisted that the students write down the key terms in their respective column, and the actual notes in their corresponding column. We wrote the scheme for the Cornell system on the blackboard, and also later added to the blackboard the notes the students had taken.

(1) Identify the key words, concepts, phrases and define them.

First we identified together with the students the key terms: educational process, curriculum, didactic strategies, content of the educational process, form of organization of the educational process, feedback.
(2) Establish connections and subordinations both between the keywords and your previous knowledge, inclusively through the use of graphic organizers, diagrams, figures.

Following this, we realized the connections and subordinations between the key terms and developed charts or cognitive organizers. The manner in which the terms were correlated was individual, as well as how the connections were achieved, each student developing their own personal organizer. To summarize, the diagrams contained the following:

Figure 1. The systemic approach to the educational process

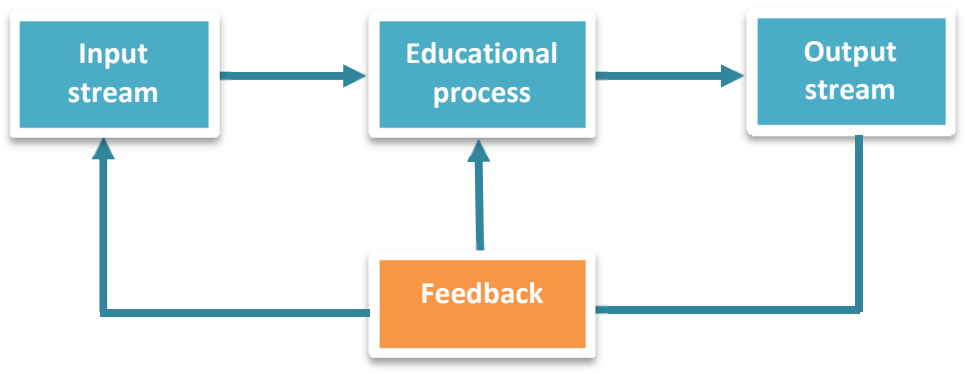

Figure 2. The components of the educational process

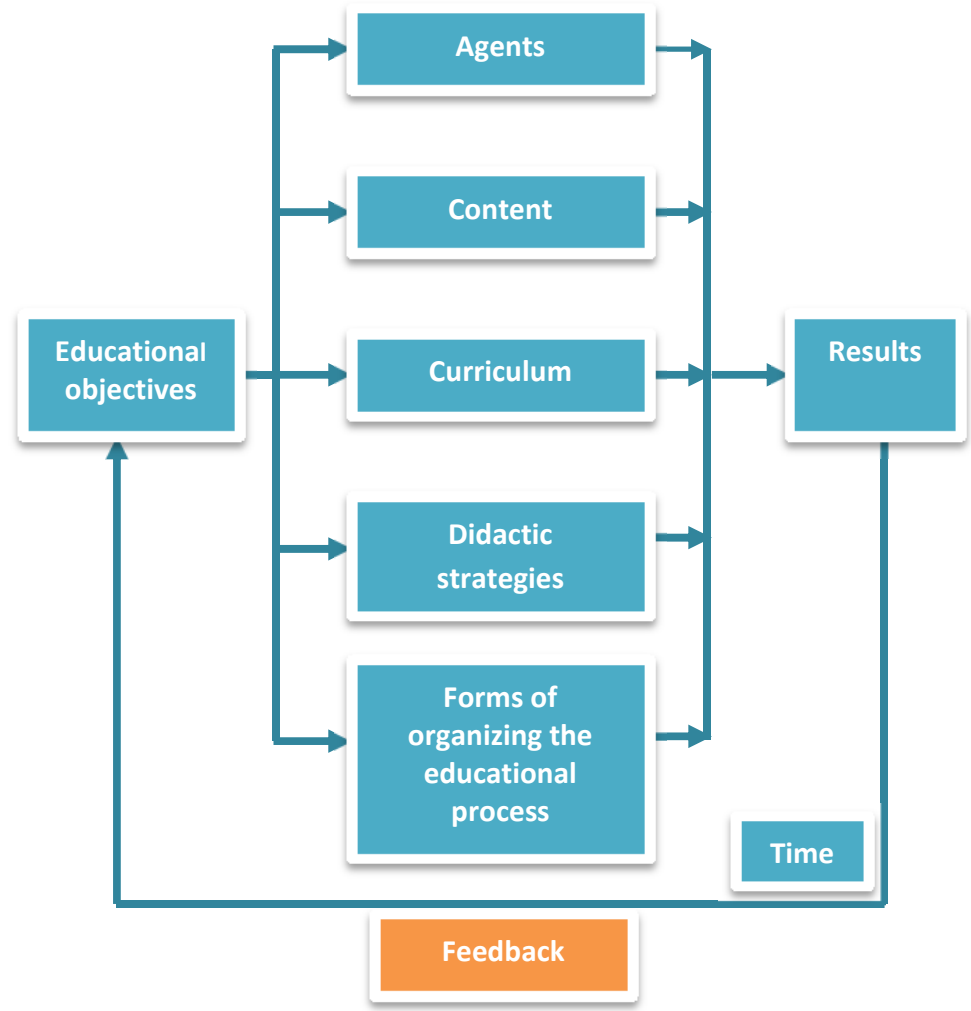

(3) Analyze the new content, realizing descriptions, explanations, and highlighting the importance of the content from a theoretical and practical perspective.

We analyzed the new content together with the students:

We defined the educational process: the complex instructiveeducational activity carried out systematically by pupils and teachers in schools, activity thanks to which the pupils acquire a system of knowledge, abilities, capacities, skills, and competencies on the basis of which they acquire scientific knowledge of reality, they form their conception of the world, their moral beliefs, their 
character traits, as well as their knowledge, research, and creation aptitudes (Bocoş, M. \& Jucan, D., 2007).

We identified each component of the educational process and have presented their characteristics along with the students (Ionescu, M., 2003). They then analyzed and highlighted the importance of each component, from both a theoretical and a practical perspective. In essence, the discussed ideas were focused on:

a) The agents are teachers, students, parents, etc. The interaction between the human resources outlines what could be called as an 'educational field', in which the teacher and the pupils remain the main elements. Modern didactics places the student in the center of attention, aiming to make him an active participant in his own formation (Ionescu, M. \& Chiş, V., Eds., 2001). The teacher thus has the task of organizing the 'educational field'; he has the responsibility of designing, conducting, and guiding school activities and extracurricular activities to a certain extent, all with the purpose of educating the students and shaping their behavior.

b) Outcomes and objectives of the educational process represent the instructional and educational requirements imposed by society - the type of results expected. These objectives correspond with certain major social requirements regarding the qualitative and quantitative level of the acquisitions that the pupils have to obtain in regards to their value judgments and their behavior. The objectives establish the following:

- What the pupils are about to know as information;

- What they have to be able to do as an action/skill;

- What attitudes and judgments to adopt.

In any activity, and thus in the didactic one as well, the goals or objectives are formulated at the beginning of the action, but they acquire a tangible form at the end, the results attained being the ones that confirm the achievement of the objectives.

c) The curriculum refers to the educational offer of the school and represents the system of direct and indirect experiences offered to those being educated and experienced by them in formal, non-formal, and informal contexts (Neacşu, I., 1985).

d) The content of the educational process is the basic support of education and consists of the bases of science and culture. The educational process conveys scientific, technical, literary and artistic, philosophical, religious, and ethical content, based on a particular logic and according to various degrees of difficulty.

e) Didactic strategies (didactic methods, teaching aids, and forms of organizing the didactic activity): didactic methodology is the system of didactic methods and procedures; it is concerned with studying the definition, the nature, the status, the functions, the classifications, and the principles of using didactic methods, both from a theoretical and a practical point of view, through the lens of a unified conception on the act of teaching and learning. The traditional instruction techniques included verbal means, chalk and a blackboard. The range of teaching aids has expanded to encompass, in addition to the audiovisual equipment (slides, films, magnetic tapes, etc.), the electronic computer (the Internet etc.), all of which have greatly amplified the classical possibilities.

f) The forms of organization of the teaching activity refer to the specific ways of designing and accomplishing the teacherstudent interactions and promoting certain types of collaboration between them, in accordance with the educational outcomes/ objectives pursued. The history of education has accredited the organization of education by classes and lessons as a proven method of operating, which has been continuously diversified and improved.

g) The whole process of education takes place in time: school year, semester, school week, school days, class hours, etc. The content of education appears segmented in time units: the teacher plans, divides, and allocates his work according to the available time.

h) The educational process is a dynamic and complex process, which can be assimilated to a complex system of constantly changing and balancing interactions. The continuous adjustment of the system is realized via reversed connection/feedback, which designates the information pertaining to the achieved results, information originating from the system's 'output'. This information is then directed back towards the 'input' of the system, so that it may be able to change its configuration according to the proposed goals. Depending on the timing of the feedback in relation to the teaching sequence, we can talk about formative feedback, which is done systematically during the entire teaching sequence and has the purpose of supporting the pupils' learning activity, and summative feedback, which is achieved at the end of the sequence and is meant to provide information about the pupils' and the teacher's performance.

(4) Ask questions about the content, reflect upon it.

By going over the new content at this point in the class, the students were encouraged to ask questions regarding the discussed content in order to retain it more easily and to reflect upon the essential points, the main ideas of the content. In general, the questions raised by the students were:

- What is the systemic approach to the educational system?

- What is the educational system?

- What are the components of the educational system?

The students reflected further on the components 'curriculum', 'didactic strategies' and 'feedback'.

Furthermore, the problematizing situations during this class focused on the following (Potolea, D., 1989):

- Establishing the relationships between the components of the educational process;

- The role of the systemic approach in the analysis of the educational process; 
- Explaining the role of feedback in the educational process, both at the macro level, but especially at the micro level.

(5) Give personal feedback on effective modalities of studying the content.

The students expressed their opinions concerning effective methods of studying this particular lesson (Vinţanu, N., 2001). Many students have stated that notes that are categorized in this manner help them when studying, and also that the diagrams are of real use, others have stated that by going through the content in this manner they have understood almost everything during the class and will just be reading the notes.

(6) Summarize the content.

We asked the students to summarize the content we had discussed in 2-3 phrases and write the phrases down in the space reserved for this purpose within the Cornell system. We then wrote the summary on the blackboard and the students in their notes.

We checked the students' notes. In the first column they had written down the keywords. In the second column they had written the definition of the educational process, the diagrams, and the characteristics of each component of the educational process. The third column was occupied by the summary of the class.

We note that we have conducted each class in this manner, observing and directing the instructive-educational activity throughout the semester. We have continuously attempted to reinforce the theoretical foundation of the students, but above all to develop their reflexivity and to determine them to make connections in their pedagogical knowledge.

\section{Conclusion}

We have continuously monitored the activity throughout the semester and have concluded that carrying out the classes in this manner has determined the students to: profoundly reflect upon their pedagogical knowledge; realize connections to the information in their previous pedagogical courses; address and ask themselves pertinent and problematizing questions; creatively and individually process the information; make observations and analytical comments based on the information; relate and logically integrate the information into their personal cognitive systems; establish links in the information, while at the same time updating the knowledge previously acquired; relate and interrelate the key pedagogical terms in a descriptive manner; structure ideas with the help of cognitive organizers; illustrate in a practical manner, through examples, the pedagogical knowledge; synthesize and organize the information; maintain a positive attitude towards the subject matter, but especially towards the job of a teacher. In essence, this course of action has supported the students' development of the skills necessary to a future teacher.

\section{References}

Bocoş, M. \& Jucan, D. (2007). Teoria şi metodologia instruirii şi Teoria şi metodologia evaluării. Repere şi instrumente didactice pentru formarea profesorilor. Cluj-Napoca: Editura Casa Cărţii de Ştiinţă.

Deese, J. \& Deese, E. K. (1979). How to Study. New York: McGrawHill.

Entwistle, N. J. \& Ramsden, P. (1983). Understanding student learning. London: Croom Helm.

Ertmer, P. A. \& Newby, T. J. (1996). The expert learner: Strategic, self-regulated and reflective. Instructional Science, 24, 1-24.

Fleming, N. D. \& Mills, C. (1992). Helping Students Understand How They Learn. The Teaching Professor, Vol. 7, No. 4. Madison, Wisconsin: Magna Publications.

Ionescu, M. \& Chiş, V. (Eds.). (2001). Pedagogie. Suporturi pentru formarea profesorilor. Cluj-Napoca: Editura Presa Universitară Clujeană.
Ionescu, M. (2003). Instrucţie şi educaţie - Paradigme, strategii, orientări, modele. Cluj-Napoca: Editura Garamond.

Jucan, D. (2009). Strategii de activitate intelectuală a studenţilor. Cluj-Napoca: Casa Cărţii de Ştiinţă.

Neacşu, I. (1985). Metode şi tehnici moderne de învăţare. Bucureşti: Tipografia Universităţii.

Potolea, D. (1989). Profesorul şi strategiile conducerii învăţării. In I. Jinga (Ed.), Structuri, strategii şi performanţe în învăţământ. Bucureşti: Editura Academiei.

Vinţanu, N. (2001). Educaţia universitară. Bucureşti: Editura Aramis. 